\title{
"Possessing with Intent to Distribute" Under the Schoolyard Statute
}

Sonja R. West $\dagger$

Police arrested Anthony McDonald for possession with intent to distribute cocaine after a search of his residence turned up about four hundred dollars in cash and twenty-two plastic ziplock bags filled with crack cocaine. ${ }^{1}$ In addition, because his residence happened to be only ninety feet from the edge of the Richardson Elementary School's playground, McDonald was charged with violating 21 USC $\S 860$, otherwise known as the "schoolyard statute." This statute doubles the penalty for certain drug offenses, including possession with intent to distribute, that are committed within one thousand feet of a school. ${ }^{3}$ The D.C. Circuit, upholding a jury verdict against McDonald under Section 860 , concluded that the statute did not require the prosecution to prove that $\mathrm{McD}$ onald had intended to distribute the drugs within the school zone, but rather just that he had intended to distribute them somewhere. ${ }^{4}$

In a different case, Lorne Coates was arrested at New York City's Penn Station in possession of four kilograms of cocaine while on a train about to depart for Washington, D.C. ${ }^{5}$ Like McDonald, Coates was indicted under the schoolyard statute for possessing with intent to distribute a controlled substance within one thousand feet of a school. ${ }^{6}$ Prosecutors brought this charge because the Taylor Business School, a technical school, was located in an office building above and adjacent to the station. ${ }^{7}$ The district court dismissed the charge under the schoolyard statute, holding that there was no evidence Coates intended to distribute within one thousand feet of a school, or even within the state of New York.

The McDonald and Coates cases exemplify an apparent disagreement between the courts regarding the scope of the mens

$\dagger$ B.A. 1993, The University of Towa; J.D. Candidate 1998, The University of Chicago.

${ }^{1}$ United States $v$ McDonald, 991 F2d 866, 868 (DC Cir 1993).

${ }^{2}$ Id.

321 USC $\$ 860$ (a) (1994).

4 MaDonald, 991 F2d at 871.

- United States $v$ Coates, 739 F Supp 146, 153 (S D NY 1990).

${ }^{6}$ Id at 148.

Id. 
rea requirement for the offense of possession with intent to distribute within one thousand feet of a school. Federal district courts in the Second, Seventh, and D.C. Circuits have ruled that the statute requires proof that the defendant intended to distribute controlled substances within the school zone. ${ }^{8}$ Recently, however, three federal appellate courts-the Third, Fifth, and D.C. Circuits-have held that prosecutors must prove only that defendants, while possessing illegal drugs in a school zone, intended to distribute the illegal drugs somewhere, even outside the school zone. ${ }^{9}$ All of these courts have examined the text and legislative history of the schoolyard statute and have debated whether it requires proof of an intent to distribute within the school zone.

Rather than join the debate, however, this Comment argues that these courts do agree generally about what types of drugrelated conduct Congress intended to reach with this statute. A fact-based analysis of the relevant cases reveals that in cases where the possession of illegal drugs poses a significant and prolonged danger to schoolchildren-for example, where the drugs were stored near a school-courts generally interpret the statute broadly, and do not require an intent to distribute within the zone. However, in cases involving a more remote and temporary danger to the students-for example, where the defendant was simply driving through the school zone-courts generally follow a narrow interpretation and do require an intent to distribute within the zone. Courts also apply a narrow reading when confronted with issues of entrapment and equal protection.

This Comment proposes that courts should explicitly rather than implicitly distinguish the different types of defendants accused of possession with intent to distribute controlled substances within a school zone. Part I reviews the current state of the law on this issue and presents the legislative history and textual arguments involved in the debate over the mens rea requirement. Part II examines the factual circumstances at issue in the relevant cases and concludes that these factual circumstances, rather than competing statutory interpretations, lead to

${ }^{8}$ United States v Alston, 832 F Supp 1, 6 (D DC 1993); United States $v$ Watson, 788 F Supp 22, 24 (D DC 1992); United States v Testa, 768 F Supp 221, 223 (N D Ill 1991); United States $v$ Roberts, 735 F Supp 537, 543 (S D NY 1990); United States $v$ Liranzo, 729 F Supp 1012, 1014 (S D NY 1990); Coates, 739 F Supp at 153. Notably, the Alston court was bound by the D.C. Circuit's interpretation of the statute established in McDonald. Alston, $832 \mathrm{~F}$ Supp at 6 . However, the Alston court held that the facts in the case were "significantly different from the facts of $\mathrm{McD}$ onald" and dismissed the schoolyard statute charge. Id at 6-7.

9 McDonald, 991 F2d at 867; United States v Rodriguez, 961 F2d 1089, 1095 (3d Cir 1992); United States $v$ Wake, 948 F2d 1422, 1430 (5th Cir 1991). 
the different results. Finally, Part III emphasizes the need to recognize these implicit categories of offenses and concludes that courts should interpret the statute narrowly and defer to Congress for clarification. This approach also would punish those defendants who significantly increase the risks of drug-related harms to children more severely than those who do not.

\section{THE CURRENT LAW AND THE DEBATE OVER STATUTORY INTERPRETATION}

The original "schoolyard statute," 21 USC $\S 845 a,{ }^{10}$ allowed enhanced penalties up to twice the usual sentence for defendants convicted of distributing controlled substances within one thousand feet of a public or private elementary or secondary school. ${ }^{11}$ Congress subsequently amended the statute to include the offense of "manufacturing" a controlled substance within one thousand feet of a school. ${ }^{12}$ Congress also expanded the definition of a school to include vocational schools, public and private colleges, junior colleges, and universities. ${ }^{13}$ In 1988 , Congress amended the statute again to include the offense of "possessing with intent to distribute" in its list of targeted crimes. ${ }^{14}$

The schoolyard statute is silent regarding the mental state required for the attendant circumstance that the offense be committed "within one thousand feet of" a school (within a "school zone"). ${ }^{15}$ The statute does incorporate Section 841(a)(1), which requires that one must act "knowingly or intentionally" with regard to the manufacture, distribution, and dispensing of

${ }^{10}$ Pub L No 98-473 § 405A, 98 Stat 2069 (1984), originally codified at 21 USC § 845a, now codified as amended at 21 USC $\$ 860$ (1994).

"98 Stat at 2069.

12 Pub L No 99-570 § 1104(a), 100 Stat 3207-11 (1986), codified as amended at 21 USC $\S 860$ (1994).

${ }^{13}$ Id.

16 Pub L No 100-690 § 6457, 102 Stat 4373 (1988), codified as amended at 21 USC $\S 860$ (1994). Also in 1988, Congress once more expanded the definition of the zone to include the area "within 100 feet of a playground, public or private youth center, public swimming pool, or video arcade facility." Id at $\$ 6458(a)$.

15 The current version of the schoolyard statute provides that:

[a]ny person who violates section $841(a)(1)$ of this title or section 856 of this title by distributing, possessing with intent to distribute, or manufacturing a controlled substance in or on, or within one thousand feet of, the real property comprising a public or private elementary, vocational, or secondary school or a public or private college, junior college, or university, or a playground, or housing facility owned by a public housing authority, or within 100 feet of a public or private youth center, public swimming pool, or video arcade facility, is ... subject to (1) twice the maximum punishment authorized by section $841(\mathrm{~b})$ of this title; and (2) at least twice any term of supervised release authorized by section $841(\mathrm{~b})$ of this title for a first offense.

21 USC $\S 860(a)$. 
controlled substances, as well as possession of controlled substances with intent to manufacture, distribute, or dispense them. ${ }^{16}$ Section 841(a)(1) does not, however, resolve whether a defendant must engage in this conduct knowingly or intentionally within a school zone to violate the "schoolyard statute."

Courts interpreting this legislative silence consistently hold that the schoolyard statute does apply to a defendant who distributes controlled substances in a school zone, regardless of whether the defendant knew that he was within a school zone. The courts reason that strict liability crimes are acceptable when they do not criminalize otherwise innocent conduct and when the legislative history suggests that Congress intended to enact a strict liability offense. ${ }^{17}$

Courts diverge, however, over the required mental state for that part of the statute penalizing offenders who possess with intent to distribute. Initially, several district courts interpreted the statute narrowly, holding that the prosecutor must show that the defendant intended to distribute the controlled substances within a school zone. ${ }^{18}$ Some of these courts reason that the ambiguous text of the statute triggers the rule of lenity. ${ }^{19}$ Others reason that Congress had intended only to target the supply of illegal drugs to those who attend, or who gather near, a school, ${ }^{20}$ not to create "an antiseptically drug-free zone."

In contrast to this approach, three circuit courts recently interpreted the statute much more broadly to reach the opposite conclusion. These courts hold that the schoolyard statute covers anyone who possesses controlled substances within a school zone with intent to distribute them somewhere, even outside the school zone. ${ }^{22}$ Advocates of this broad interpretation argue that Congress did intend to create a "cordon sanitaire' to bar dealers

${ }^{16} 21$ USC \& 841(a)(1) (1994).

${ }^{17}$ See, for example, United States $v$ Pitts, 908 F2d 458, 461 (9th Cir 1990); United States $v$ Holland, 810 F2d 1215, 1223 (DC Cir 1987); United States $v$ Falu, 776 F2d 46, 50 (2d Cir 1985). See generally William G. Phelps, Validity and Construction of 21 USCS $\$ 860$ Enhancing Penalty for Drug Distribution if Offense Occurs Within 1,000 Feet of School, College, or University, 108 ALR Fed 783, 791-98 (1992).

${ }^{18}$ See, for example, United States $v$ Testa, 768 F Supp 221, 223 (N D Ill 1991); United States $v$ Roberts, 735 F Supp 537, 543 (S D NY 1990).

${ }^{19}$ See, for example, United States $v$ Watson, 788 F Supp 22, 24 (D DC 1992); Roberts, 735 F Supp at 542-43; United States $v$ Liranzo, 729 F Supp 1012, 1014 (S D NY 1990).

${ }^{20}$ See, for example, United States v Alston, 832 F Supp 1, 7 (D DC 1993); Testa, 768 F Supp at 223; Coates, 739 F Supp at 153.

${ }^{21}$ Roberts, 735 F Supp at 541 n 6 (explaining the government's position).

${ }^{2}$ McDonald, 991 F2d at 867; United States $v$ Rodriguez, 961 F2d 1089, 1095 (3d Cir 1992); United States $v$ Wake, 948 F2d 1422, 1430 (5th Cir 1990). 
from even fleetingly or accidentally passing within 1000 feet of a school." ${ }^{\text {23 }}$

\section{A. Arguments in Favor of a Narrow Construction}

The district courts that considered the mens rea requirement of the schoolyard statute followed one of two lines of reasoning. Some courts decided that the statute is ambiguous and thus triggers the rule of lenity. ${ }^{24}$ Others, however, simply found that the statute did not apply to the facts in the case before them. ${ }^{25}$ Each of these courts placed varying importance on the plain meaning of the statute, the legislative history, and the applicability of the rule of lenity.

\section{Plain meaning.}

Some of the district courts considered the plain meaning of the statute. These courts concluded either that the plain meaning of the statute tends to support a narrow interpretation, ${ }^{26}$ or alternatively that the text "is simply unclear." ${ }^{.27}$ Notably, courts in the Southern District of New York have reached both conclusions. For example, the court in United States $v$ Liranzo ${ }^{28}$ concluded that the statute is "sufficiently ambiguous" to justify applying the rule of lenity, and also agreed with other district courts that the "better and more logical construction" of the statute includes only those who intend to distribute within the school zone. ${ }^{29}$ The Liranzo court reasoned that the "more natural reading" of the statute would interpret the phrase "within one thousand feet of" as modifying the verb closest to it: distributing, not possessing. ${ }^{30}$ Thus this reading requires that the distributing, not

${ }^{25}$ Roberts, $735 \mathrm{~F}$ Supp at $541 \mathrm{n} 6$ (summarizing the government's argument in this case). See also Wake, 948 F2d at 1431-32.

${ }^{24}$ United States $v$ Watson, 788 F Supp 22, 24-25 (D DC 1992); United States $v$ Roberts, 735 F Supp 537, 542-43 (S D NY 1990); United States v Liranzo, 729 F Supp 1012, 1014 (S D NY 1990).

${ }^{25}$ United States $v$ Alston, 832 F Supp 1, 7 (D DC 1993); Testa, 768 F Supp at 223; Coates, 739 F Supp at 153.

${ }^{23}$ Watson, 788 F Supp at 24; Liranzo, 729 F Supp at 1013-14.

${ }^{27}$ Roberts, 735 F Supp at 540.

23 729 F Supp 1012, 1014 (S D NY 1990).

${ }^{2}$ Id. See also Roberts, 735 F Supp at 541-43 (applying the rule of lenity while also rejecting as "unconvincing" the government's textual arguments that Congress intended to prevent possession in a school zone with intent to distribute elsewhere); Watson, $788 \mathrm{~F}$ Supp at 24 (applying the rule of lenity but also noting that the "more logical reading" of the statute would support a narrow interpretation).

30729 F Supp at 1014, citing William Strunk, Jr. and E.B. White, The Elements of Style 30 (Macmillan 3d ed 1979) ("Modifiers should come, if possible, next to the word they modify."). 
just the possessing, take place within a school zone. Although agreeing that different wording would have clarified intent, in United States $v$ Roberts ${ }^{31}$ the court found the statute's syntax to be "neither 'unnatural' nor necessarily indicative of congressional intent" and held that the text is ambiguous.

The courts' finding that the statute covers only those who intend to distribute within the school zone focused on the fact that mere possession is not covered by the statute. These courts reasoned that the omission of possession alone indicates that the statute does not simply increase penalties for all drug offenses occurring within the school zone. Instead, it identifies only a select few. To interpret the statute to include possession with an intent to distribute outside of the school zone, the courts concluded, "would effectively create an enhanced penalty for mere possession in the vicinity of a school, even though [the schoolyard statute] criminalizes only possession with intent to distribute. ${ }^{932}$

The fact that Congress omitted simple possession and even consumption from the schoolyard statute also lends support to the argument that Congress intended to deter drug distributions or transactions near schools, rather than to create, as the appellate courts suggest, a completely drug-free school zone. ${ }^{33}$ Therefore, the district courts concluded that the statute covers only active conduct near schools, not more passive behavior such as possession. ${ }^{34}$

\section{Legislative history.}

Having found the text of the statute inconclusive, some courts that interpreted the statute narrowly turned to the legislative history to aid their decisions. ${ }^{35}$ Some courts found no helpful history while others concluded that the legislative history is ambiguous. ${ }^{36}$ Again, however, the courts found that to the extent

31735 F Supp 537, 539-40 (S D NY 1990).

${ }^{32}$ Testa, 768 F Supp at 223.

${ }^{33}$ Id; Roberts, 735 F Supp at 541 ("Distributing, manufacturing, and possessing with intent to distribute are all forms of behavior leading to the supply of drugs within the vicinity of the school."). The conflicting views of the appellate courts are summarized at notes 45-53 and accompanying text.

${ }^{31}$ Testa, $768 \mathrm{~F}$ Supp at 223 . The Testa court also mentioned that "although to be sure a statute's title is not viewed as part of the statutory language, it is worth noting that Section $845 \mathrm{a}$ is captioned Distribution or Manufacturing In or Near Schools and Colleges." Id.

${ }^{35}$ See, for example, Watson, $788 \mathrm{~F}$ Supp at 24.

${ }^{36}$ See id (finding the legislative history to be ambiguous); Roberts, 735 F Supp at 538 ("There is no legislative history accompanying the amended statute and scant legislative history surrounding the original version."). 
they could discern an intent, it supported a narrow interpretation. ${ }^{37}$

Unlike one of the appellate courts, ${ }^{38}$ none of the district courts discussed in detail the statements made on the floor by proponents of the statute. Several of the district courts did, however, refer to the Second Circuit's opinion in United States $v$ Falu, which relied on Senate floor statements to conclude that Congress "sought to create a drug-free zone around schools."39 Although this conclusion tends to support a broad reading of the statute, the district courts narrowed Falu by reasoning that it applies only to actual distributions within the zone, not the mere existence of controlled substances near schools. ${ }^{40}$

\section{The rule of lenity.}

Many of the district courts applied the rule of lenity due to ambiguities in the statute. ${ }^{41}$ When a court's interpretation of a statute fails to resolve the ambiguity on its face, this rule mandates that all ambiguity be resolved in favor of the defendant. ${ }^{42}$ This canon of statutory construction, known as the rule of lenity, derives from the dual policy considerations of notice and separation of powers. ${ }^{43}$ The perceived ambiguity in the text of the statute and the lack of legislative history has led these courts to interpret the law narrowly in favor of the defendant. ${ }^{44}$

\section{B. Arguments in Favor of a Broad Construction}

The three appellate courts that addressed this issue all interpreted the schoolyard statute broadly, thus requiring the government to prove only that the defendant was present in a school zone and intended to distribute illegal drugs somewhere. ${ }^{45}$ These

${ }^{37}$ Watson, 788 F Supp at 24, citing United States $v$ Falu, 776 F2d 46, 50 (2d Cir 1985) (quoting congressional sponsor as stating that the purpose of the statute was to "deter drug distribution in and around schools ....").

See Wake, 948 F2d at 1431-33.

${ }^{39}$ See, for example, Watson, 788 F Supp at 24; Roberts, 735 F Supp at 541; Liranzo, 729 F Supp at 1014, all three referring to United States v Falu, 776 F2d 46, 50 (2d Cir 1985) (holding that the schoolyard statute applies to aiders and abettors who are present during a transaction in a school zone involving controlled substances).

${ }^{40}$ See, for example, Roberts, 735 F Supp at 541; Liranzo, 729 F Supp at 24.

${ }^{4}$ See, for example, Roberts, 735 F Supp at 542 ("[A]mbiguity concerning the ambit of criminal statutes should be resolved in favor of lenity."); Liranzo, 729 F Supp at 1014, citing Rewis $v$ United States, 401 US 808, 812 (1971).

${ }^{2}$ Bell v United States, 349 US 81, 83 (1955).

${ }^{43}$ Roberts, 735 F Supp at 542-43 (citations omitted).

4 Id at 543; Liranzo, 729 F Supp at 1014.

McDonald, 991 F2d at 867; United States $v$ Rodriguez, 961 F2d 1089, 1095 (3d Cir 1992); Wake, 948 F2d at 1430. 
holdings rest on the theory that Congress intended to eradicate controlled substances as completely as possible from school zones. ${ }^{46}$ Like the district courts, the appellate courts also considered the plain meaning of the text, the legislative history, and the applicability of the rule of lenity.

\section{Plain meaning.}

The court in United States $v$ Rodriguez ${ }^{47}$ began with the grammatical reasoning that the statute "applies to three types of criminal conduct: distributing controlled substances, possessing controlled substances with the intent to distribute, and manufacturing controlled substances." For the cases falling into the first and third categories, it was clear that it was the action, the "distributing" or the "manufacturing," that must occur within the school zone. Therefore, the Rodriguez court concluded, it is also the action in the second group, the "possessing," that must take place within one thousand feet of a school-not the intended distribution..$^{48}$

Courts that interpreted the statute broadly also pointed to the amendments that added "manufacturing" in 1986 and "possessing with intent to distribute" in 1988 as support for their view. They claimed that the statute originally provided a penalty only for those who distribute controlled substances within one thousand feet of a school. However, the addition of "manufacturing" indicated Congress's intention to eradicate even the mere presence of illegal drugs near schools. ${ }^{49}$ As the Rodriguez court explained:

By prescribing enhanced penalties for the manufacture of drugs near a school (regardless of the intended site of distribution), Congress made clear that it did not wish to confine the schoolyard statute to cases in which a defendant distributes or intends to distribute drugs near a school. Rather, Congress was more broadly concerned about serious drug crimes that occur in proximity to schools. ${ }^{50}$

In United States $v$ Wake, ${ }^{51}$ the Fifth Circuit took a different approach to the issue. Relying on circuit precedent, the Fifth Cir-

\footnotetext{
${ }^{46}$ See Wake, 948 F2d at 1430 (referring to "the congressional purpose to create a 'drug-free zone' around our nation's schools").

17961 F2d 1089, 1092 (3d Cir 1992).

48 Id.

49 Wake, $948 \mathrm{~F} 2 \mathrm{~d}$ at 1431.

${ }^{5}$ Rodriguez, $961 \mathrm{F2d}$ at 1092.

51 948 F2d 1422, 1430 (5th Cir 1991).
} 
cuit declared that "possessing with intent to distribute" is synonymous with "felony possession." This reasoning rested upon the assumption that, if the defendant possesses a significantly large quantity of controlled substances, he must intend to distribute them. Because "[t]his category of possession is made a felony by $\S 841$, which ... . is referenced in the schoolyard statute," the Fifth Circuit concluded that "possessing with intent to distribute" equals "felony possession." ${ }^{\text {"Un }}$ Under this reading of the statute, anyone meeting the felony possession standards would be subject to the extra penalties imposed by the schoolyard statute-no matter where they intended to distribute the illegal drugs-as long as they were caught possessing the controlled substances in the school zone.

A commentator critical of this reasoning argues that no provision in the schoolyard statute states that intent is automatic when a person possesses a certain quantity of controlled substances. Furthermore, "the quantity of drug possessed is not a constituent element of the offense of possession with intent to distribute"; rather, "quantity is only relevant to punishment." $\mathrm{He}$ concludes, therefore, that the intent requirement of the schoolyard statute is not automatically satisfied in these cases. ${ }^{55}$

\section{Legislative history.}

The Wake and Rodriguez courts also turned to the legislative history of the schoolyard statute to support their broad interpretation. For example, the Wake court stressed statements made on the floor by proponents of the statute. The court pointed to statements by Senator Hawkins warning that Congress needed to "send a signal to drug dealers that we will not tolerate their presence near our schools. ${ }^{\text {"56 }}$ It also noted a statement by Senator Chiles that Congress's concern was to eradicate illegal drugs around schools. ${ }^{67}$ Both the Wake and Rodriguez courts concluded

\footnotetext{
${ }^{62}$ Id at 1430-31.

${ }^{53}$ Id, citing United States $v$ Hernandez-Beltran, 867 F2d 224, 226 (5th Cir 1989) ('The intent to distribute may be inferred from the possession of a large quantity of the drug."); United States v Mendoza, 722 F2d 96, 103 (5th Cir 1983) (" $[\mathrm{P}]$ ossession of a quantity of narcotics so large that it could not be used by the possessor alone justifies the conclusion that possession was for distribution.").

${ }_{4}^{4}$ Russel D. Hall, Casenote, United States v. Wake: Fifth Circuit Hands Down HardLine Intent Requirement in Schoolyard Statute, 10 Cooley L Rev 443, 452 (1993), quoting United States v Patrick, 959 F2d 991, 996 n 5 (DC Cir 1992).

${ }^{55}$ Hall, Casenote, 10 Cooley L Rev at 451.

${ }^{56}$ Wake, $948 \mathrm{~F} 2 \mathrm{~d}$ at 1431 (emphasis added and internal quotation marks omitted), quoting 130 Cong Rec $S 559$ (daily ed Jan 31, 1984).

${ }^{57}$ Wake, 948 F2d at 1431, quoting 132 Cong Rec S 10,426 (daily ed Aug 5, 1986).
} 
that Congress intended to eliminate the mere presence of controlled substances within the school zone, thus supporting a broad interpretation.

In McDonald, however, the D.C. Circuit found the legislators' statements not "particularly persuasive, ${ }^{358}$ and relied instead on its plain meaning interpretation of the statute. In fact, the McDonald court admitted that several of the statements, "like the statute itself, might plausibly support either of two interpretations, one favoring our view [and] the other the district court's." 59

\section{The rule of lenity.}

None of the appellate courts found that the statute triggered the rule of lenity. In Rodriguez, the Third Circuit found the rule of lenity inapplicable because "the statute's plain language persuades us that no ambiguity exists. ${ }^{.60}$ In Wake, the Fifth Circuit agreed, adding that "even assuming ambiguity, we need not resort to the rule of lenity, because we have ascertained a legislative purpose behind the schoolyard statute to create a drug-free 1,000 foot zone." In McDonald, the D.C. Circuit also found that the statute was not ambiguous and noted that whatever uncertainty might exist, "it is far from 'grievous,' an essential condition for applying the canon." ${ }^{n 2}$

\section{FACT-BASED ANALYSIS OF THE RELEVANT CASES}

While the divergent results in the district and appellate courts suggest a sharp division between the courts, a fact-based analysis of the relevant cases indicates otherwise. When the cases are examined in terms of "permanent resident" versus "transient" offenders, there appears to be general agreement among the courts about which defendants deserve enhanced punishment and which do not. "Permanent resident" offenders are those who, while intending to distribute the controlled substances outside of the school zone, are still involved in prolonged, established, and substantial drug-related activities within the school zone. Because of their established footholds in the school zone, these defendants are more likely to engage repeatedly in prohibited activities near schools. They usually store large

\footnotetext{
${ }^{6 s}$ McDonald, 991 F2d at 870.

${ }^{s 9}$ Id.

${ }^{\infty}$ Rodriguez, $961 \mathrm{~F} 2 \mathrm{~d}$ at 1094.

${ }^{61}$ Wake, 948 F2d at 1433.

${ }^{\infty}$ McDonald, 991 F2d at 870.
} 
amounts of controlled substances in crack houses or operate drug rings from within the school zone. "Transient" offenders are those who intend to distribute outside of the school zone and whose drug activities near schools are for short periods of time and involve a less established connection to the school zone. Because of their infrequent visits to the school zone, these dealers are less likely to engage in illegal drug-related conduct repeatedly near schools. They are often simply driving through the school zone in a vehicle or waiting at a bus station on their way to deliver the controlled substances outside of the school zone.

Cases in which courts interpreted the schoolyard statute narrowly involved transient defendants, while those holdings based on a broader view of the statute involved permanent resident defendants. Defendants convicted of storing illegal drugs or operating drug distribution rings from within the school zone were more likely to receive the enhanced penalties. Conversely, when arrests were made in bus or train stations, or when defendants were only driving through the school zone, the defendants were more likely to avoid the enhanced punishment of the schoolyard statute. Interestingly, in one instance where a D.C. district court refused to follow the broad interpretation of the statute set forth by the D.C. Circuit, the decisions of both courts comported with this distinction. ${ }^{63}$

\section{A. Cases Interpreting the Statute Broadly}

All three federal appellate courts to address this issue-the Third, Fifth, and D.C. Circuits-have determined that the schoolyard statute requires only a showing of possession within a school zone and the intent to distribute anywhere. A closer look at the facts of the cases, however, shows that all three cases involved permanent resident offenders who significantly increased the risk of drug-related dangers to schoolchildren.

All three of the circuit courts stressed the heightened danger to students imposed by the defendants. They also recognized possible circumstances where defendants may not cause as much danger to schoolchildren. The first appellate court to address the issue was the Fifth Circuit in Wake. ${ }^{64}$ Police arrested Wake for possession with intent to distribute cocaine after finding evidence that he ran a drug distribution ring out of a rented office four

${ }^{6}$ United States $v$ Alston, 832 F Supp 1, 6-7 (D DC 1993), declining to follow McDonald, 991 F2d 866. See also text accompanying notes 94-102.

b4 $948 \mathrm{~F} 2 \mathrm{~d} 1422$. 
hundred feet from a public high school. ${ }^{65}$ Caught with marijuana, drug paraphernalia, drug records, and two kilograms of cocaine in his office, ${ }^{66}$ Wake was a typical permanent resident offender.

Interpreting the statute broadly, the Fifth Circuit recognized the potential for situations that might be exempted from the statute: "Not before us is whether a court might adopt an "implied exception' to $\S 845 \mathrm{a}$ [now $\S 860$ ] for a case where, for example, the possessing defendant merely speeds underneath a school in a subway train." ${ }^{\text {"67 }}$ Although it is unclear exactly what the court meant by an "implied exception" to the statute, the court emphasized that the fact pattern in Wake was "the paradigm of the conduct Congress sought to deter through the schoolyard statute penalty enhancements." ${ }^{\text {"68 }}$ Furthermore, the Wake court repeatedly stressed the importance of increased danger to schoolchildren. The court found that the existence of controlled substances in the school zone and the possibility of concomitant crimes "increase[ ] greatly the likelihood that schoolchildren will come in contact with them or otherwise be placed directly in harm's way."

The Third Circuit was the next to face this problem. In Rodriguez, two police officers saw Rodriguez enter a house located within one thousand feet of an elementary school and leave carrying a pillowcase believed to contain cocaine. As the officers followed the car, packages of cocaine were thrown out of the car's windows. ${ }^{70}$ Rodriguez was indicted for numerous offenses, including "maintaining a building for the purpose of storing a controlled substance. ${ }^{371}$ Although this count was later dismissed, ${ }^{72}$ it suggests that Rodriguez meets the permanent resident profile for maintaining an established connection within the school zone for an extended period of time. Additionally, the Third Circuit emphasized that, because Rodriguez abandoned the controlled substances while fleeing from police, she increased the danger that the illegal drugs might "find their way into students' hands."

Like the Wake court before it, the Rodriguez court also recognized that some defendants might be caught under the schoolyard statute even if they did not significantly increase the dan-

\footnotetext{
${ }^{65}$ Id at 1424-25.

${ }^{66}$ Id at 1425 .

ir Id at $1433 \mathrm{n} 9$.

${ }^{63}$ Id.

Id at 1433.

$70961 \mathrm{~F} 2 \mathrm{~d}$ at 1090.

71 Id at $1090 \mathrm{n} 1$.

72 Id at 1090.

${ }^{73}$ Id at 1094.
} 
gers to the school's children. The court concluded that "[n]o matter how interpreted, the coverage of the schoolyard provision would not correspond precisely with the class of cases involving increased risk to students." ${ }^{74}$ The Rodriguez court suggested that trial courts would be able to eliminate "any unwarranted increase in the sentence" for these "extreme cases" through the discretion granted to judges by the Sentencing Guidelines. ${ }^{75}$

Most recently, the D.C. Circuit confronted the schoolyard statute in McDonald. Again, the court's broad construction of the statute corresponded with a permanent resident defendant. McDonald lived in a rented second floor bedroom of a house located across the street from an elementary school. ${ }^{76}$ Only ninety feet separated his front door from the edge of the school's playground. ${ }^{77}$ The police found cash and more than five grams of crack cocaine in his room. ${ }^{78}$

Throughout its opinion, the court stressed the importance of protecting students from increased risks. The court reasoned that the interpretation of the schoolyard statute "must rest ... on the desire to give students increased protection from the violence often accompanying serious drug offenses, and from the threat of having their lives corrupted through proximity to drug traffickers and their wares. ${ }^{.79}$

In agreement with the like-minded appellate courts before it, the $M c$ Donald court acknowledged the potential inequities of this broad interpretation of the statute: "We do not deny that traffickers intending to distribute illegal drugs near a school may be deserving of more punishment than traffickers bent on selling across town. ${ }^{\prime 80}$ Like the Rodriguez court, the McDonald court supported relying on the Sentencing Guidelines when lenity is "appropriate."

These three cases illustrate the profile of the permanent resident offender who, while possessing with an intent to distribute outside of the school zone, significantly increases the risk of students having contact with illegal drugs or drug-related violence. Each of these defendants had a permanent foothold inside the door of the forbidden zone, thereby suggesting a prolonged stay, a likelihood of repeat conduct, and extensive activities near

\footnotetext{
${ }^{3} \mathrm{Id}$.

${ }^{75}$ Id at $1095 \mathrm{n} 8$.

${ }^{76} 991$ F2d at 868.

${ }^{77} \mathrm{Id}$.

$7 \mathrm{Id}$.

${ }^{79}$ Id at 869.

${ }^{80}$ Id.

12 Id at 871.
} 
the school. Accordingly, all three courts stressed the increased risk these defendants imposed on students. Likewise, all of the courts recognized the potential for defendants who did not pose such an increased risk to be caught under the umbrella of the schoolyard statute as broadly interpreted.

\section{B. Cases Interpreting the Statute Narrowly}

Several district courts reached the opposite conclusion from the appellate courts. They interpreted the statute narrowly to require proof that the defendant intended to distribute the controlled substances within the school zone. All but one of these cases involved transient offenders, and all the defendants in these cases were either in vehicles when arrested or waiting for a vehicle to take them outside the school zone. ${ }^{82}$

The Southern District of New York first confronted this issue in Liranzo. Police arrested Liranzo in the Port Authority bus terminal with about one kilogram of cocaine. The terminal happened to be within one thousand feet of a private elementary school. ${ }^{83}$ Because Liranzo was taking the cocaine to Pennsylvania for delivery to another person, ${ }^{84}$ she typifies the transient offender. Finding that the schoolyard statute was ambiguous-and thus applying the rule of lenity-the court decided that increasing Liranzo's punishment would contravene the purpose of the statute: to "deter drug distribution in and around schools,' including 'transactions' which took place near where students gather.... ${ }^{m 55}$

Another district court in the Southern District of New York reached the same conclusion in Roberts, in which Roberts and two others were arrested at Penn Station in New York City with about thirteen ounces of cocaine ${ }^{86}$ Roberts had taken possession of the cocaine in Harlem, stopped at a hotel to meet one of the

\footnotetext{
62 The only decision that conflicts with the permanent resident-transient distinction is a case in the Northern District of Ilinois. In United States $v$ Testa, 768 F Supp 221, 222 (N D Ill 1991), the court applied the rule of lenity in the case of a defendant who had been charged with keeping twenty kilograms of cocaine in a stash house within one thousand feet of a public high school-a classic permanent resident offender. Based on a grammatical analysis of the text and the court's agreement with the analysis of the Roberts court, the court concluded that "the United States is . . . just plain wrong" in its broad interpretation of the statute. Id at 223. Although the facts suggest that the defendant was a permanent resident offender, the court interpreted the statute narrowly. Unlike all the other opinions involving permanent resident defendants, the ruling fails to mention a concern for the safety of schoolchildren.

83 729 F Supp at 1013.

84 Id.

${ }^{85}$ Id at 1014 , referring to Falu, 776 F2d at 50.

${ }^{86} 735$ F Supp at 537-38.
} 
other offenders, and proceeded to Penn Station. The offender was trying to board a train to Delaware with the illegal drugs when Roberts was arrested. The hotel was located within one thousand feet of the John Jay College of Criminal Justice. ${ }^{87}$

In applying the rule of lenity to this transient offender, the court came closer than any other to recognizing expressly the difference between defendants with a more permanent connection to a school zone and those who are just passing through. As the court explained:

Whereas distribution relates to supply and manufacturing implies both a foothold or some establishment leading to the supply of drugs within the vicinity of the school, possessing, while passing through the [school] zone, with intent to deliver elsewhere, does no more to adulterate the [school] zone with a supply of drugs than a smoker with an unopened pack of cigarettes does to adulterate a non-smoking section or zone. ${ }^{88}$

A third Southern District of New York case also deals with transient defendants arrested while attempting to leave Manhattan's Penn Station. In Coates, drug enforcement officers arrested Coates and another defendant while they were on a train preparing to depart for Washington, D.C. ${ }^{89}$ The defendants were caught with four kilograms of cocaine.$^{90}$ Prosecutors charged both defendants under the schoolyard statute based on the presence of the Taylor Business School, a technical school located in an office building within one thousand feet of Penn Station. ${ }^{91}$ On crossexamination, Coates testified that he and the other defendant had intended to take the cocaine to Maryland..$^{92}$ In dismissing the charges under the schoolyard statute, the court considered the problem of enhancing the punishment of a transient offender like Coates. It found that to do so "stretches the scope of the statute beyond logical and acceptable bounds. ... [It] would ... mandate charging a schoolhouse count every time defendants on trains, or any other means of transportation, speed by a school on their way to a narcotics sale." 93

Following the D.C. Circuit's broad interpretation of the statute in McDonald, discussed above as a classic permanent resi-

\footnotetext{
${ }^{87}$ Id at 538.

${ }^{88} \mathrm{Id}$ at $541 \mathrm{n} 6$.

${ }^{89} 739$ F Supp at 149 .

${ }^{90}$ Id at 148.

${ }^{91}$ Id.

s2 Id at 153.

${ }^{33}$ Id.
} 
dent case, a D.C. district court judge considered the case of a transient defendant. In United States $v$ Alston, ${ }^{94}$ the court dismissed the schoolyard statute charge against a defendant in a case where the facts suggested that police entrapment was involved. Police had spotted Alston driving a possibly stolen car while outside of the school zone. The officers followed Alston and did not pull the car over until he was within one thousand feet of a public high school. A search of the car revealed a glove compartment filled with plastic bags of cocaine and three handguns. ${ }^{95}$ Although the court acknowledged that the officers might have waited to pull Alston over in order to await back-up before stopping, it also suggested that the police may have been seeking an opportunity to charge Alston under the schoolyard statute. ${ }^{96}$ This dictum suggests that the court was concerned with possible entrapment, particularly the power that investigating agents have to influence sentences of defendants prior to their arrest. ${ }^{97}$

${ }^{94} 832$ F Supp 1, 7 (D DC 1993).

${ }_{95}$ Id at 2.

${ }^{96}$ See id at 7.

${ }^{97}$ For a discussion of sentencing entrapment, see Andrew G. Deiss, Comment, Making the Crime Fit the Punishment: Pre-Arrest Sentence Manipulation by Investigators Under the Sentencing Guidelines, 1994 U Chi Legal F 419. In 1993, the Eighth Circuit recognized the defense of sentencing entrapment, allowing for a downward departure from the Federal Sentencing Guidelines for circumstances where "outrageous official conduct . . overcomes the will of an individual ${ }^{p}$ for the purpose of increasing the defendant's sentence. United States $v$ Barth, $990 \mathrm{~F} 2 d$ 422, 424 (8th Cir 1993) (internal quotations omitted). In Barth, not a schoolyard statute case, the defendant claimed that undercover offcers had continued to buy drugs from him until he reached the "magic number" of grams that would trigger a longer mandatory sentence. Id. Although finding that the facts did not support Barth's claim of sentencing entrapment, the Eighth Circuit recognized that such entrapment may occur. Id at 424-25. Like the Barth court, several other courts have recognized the potential for a sentencing entrapment defense. However, to date no appellate court has found it applicable to the facts in the case before it. See, for example, United States $v$ Appel, 1996 US App LEXXIS 34013, *5 (9th Cir) (unpublished opinion) (holding that the district court's finding that there was no sentencing entrapment was not clearly erroneous); United States $v$ Shephard, 4 F3d 647, 650 (8th Cir 1993) (holding that arguments that the defendant was entrapped into selling a different drug "were not properly sentencing entrapment arguments" but rather theories of entrapment on the elements of his crimes); United States $v$ Connell, 960 F2d 191, 194-96 (1st Cir 1992) (Despite defendant's claim of sentencing entrapment, the evidence showed that defendant carried out the final transaction with full knowledge that he was handling drug money, and thus, a five-level increase on the ground that he knew or believed that laundered funds were criminally derived property was not clearly erroneous.). Nevertheless, the debate over sentencing entrapment is still unresolved. The Third Circuit has not yet decided the validity of the sentencing entrapment defense. United States $v$ Raven, 39 F3d 428, 438 (3d Cir 1994). The Seventh and Eleventh Circuits have rejected the defense as a matter of law. United States $v$ Garcia, 79 F3d 74, 76 (7th Cir), cert denied, 117 S Ct 158 (1996); United States $v$ Williams, 954 F2d 668, 673 (11th Cir 1992). The Fourth Circuit has distinguished between sentencing entrapment and sentencing factor manipulation, a broader theory, and expressed "skepticism" about the latter doctrine. United States $v$ Jones, 18 F3d 1145, 1152-54 (4th Cir 1994). If adopted, the sentencing entrapment de- 
Emphasizing that the purpose of the schoolyard statute is to prevent danger to schoolchildren, the D.C. district court noted that to enhance a sentence under the schoolyard statute when there are entrapment concerns would encourage police to chase suspected drug offenders through school zones or wait to arrest them until a schoolyard statute violation had also occurred. ${ }^{98}$ This incentive, the court stated, "would bring 'violence' to the schools, and is contrary to the purpose of the statute. ${ }^{n 99}$

The court conceded that it was bound by the broad interpretation of the statute set forth in McDonald, ${ }^{100}$ but ruled in favor of the defendant nonetheless. The McDonald court, the court reasoned, "simply did not visualize the situation where the police have an opportunity to stop a suspect prior to the suspect reaching a school zone, but choose not to do so until after the suspect has traveled through that zone."101 Pointing to the stark differences between the two fact situations and emphasizing again the purpose of the statute, the court dismissed the charge. ${ }^{102}$

These district court cases all involve transient offenders, and all of them fall outside the courts' narrow construction of the schoolyard statute dictated, in part, by the courts' application of the rule of lenity. These defendants were all in cars or attempting to board buses or trains passing through the school zone. Most significantly, none of these defendants had a permanent foothold or established connection to the school zone. Indeed, one can infer from the records summarized in the reported opinions that these defendants did not reside within the school zone; did not conduct their drug activities primarily within the school zone; and did not store large amounts of controlled substances within the school zone. These factors in the aggregate suggest that these

fense may limit the potential for abuse of discretion under the schoolyard statute.

${ }^{96}$ See Alston, 832 F Supp at 7.

${ }^{99}$ Id.

${ }^{10}$ Id at 6.

${ }^{101}$ Id at 7.

${ }^{102}$ Id. The government did not appeal the dismissal of the schoolyard statute charge but it did appeal another issue in the case. United States $v$ Alston, 1995 US App LEXIS 38530. An earlier, pre-McDonald D.C. district court also pointed out the possible entrapment and equal protection concerns that a broad interpretation would engender: "[G]iven the likelihood that most drug transactions in the District of Columbia necessarily occur near a school or playground simply because in this urban area there are schools or playgrounds almost everywhere, the United States Attorney would have virtually unfettered authority under the statute to charge each drug defendant either once or twice for essentially the same offense." United States $v$ Watson, 788 F Supp 22, 25 (D DC 1991). Noting the city's almost four hundred schools as well as the playgrounds, colleges, and video arcades also covered by the statute, the court insisted that it would not be appropriate to give the statute "such a broad, so overreaching meaning" without clearer language. Id at $25 \& n 5$. 
transient offenders are less likely to have a significant effect on the safety of students through increases in the drug supply or drug-related violence.

\section{Two Possible Solutions}

A study of the statutory interpretation of the schoolyard statute combined with a fact-based examination of the relevant cases leads to the conclusion that courts are distinguishing between permanent resident and transient offenders. Courts need to follow a uniform approach that is faithful to the statute. This Comment contends that courts have two options. First, they may choose to interpret the statute broadly and rely on the discretion granted to them by the Federal Sentencing Guidelines either to eliminate or to reduce the penalty enhancements for transient offenders. Alternatively, the courts may choose to interpret the statute narrowly, thereby passing to Congress the duty to amend the statute and lay out more clearly what factors courts should consider in sentencing.

\section{A. A Proposal to Interpret the Statute Broadly and Rely on Judicial Discretion Under the Federal Sentencing Guidelines}

The courts may choose to interpret the schoolyard statute broadly and find that the prosecution must only prove possession within a school zone and intent to distribute the illegal drugs somewhere. Courts can still impose sentences in accordance with their tacit permanent resident-transient offender distinction by relying on the discretion granted to them under the Federal Sentencing Guidelines.

In 1984, the United States Sentencing Commission promulgated a set of sentencing guidelines under the Sentencing Reform Act that greatly curtailed the discretion judges have when sentencing defendants for certain offenses. ${ }^{103}$ Although the Guidelines, which consist of a grid of forty-three offense levels and six criminal history categories, do significantly limit the discretion of the judge, there are some adjustments to the offense level still left entirely under the judge's control. For example, the court is allowed to impose a sentence not within the Guidelines' range for

\footnotetext{
${ }^{103} 28$ USC §§ 991-98 (1994). The Act charges the Commission with designing guidelines meant to "provide certainty and fairness in meeting the purposes of sentencing, avoiding unwarranted sentencing disparities among defendants with similar records who have been found guilty of similar criminal conduct while maintaining sufficient flexibility to permit individualized sentences when warranted by mitigating or aggravating factors not taken into account in the establishment of general sentencing practices." 28 USC $\S 991(b)(1)(B)$.
} 
"aggravating or mitigating circumstance[s] of a kind, or to a degree, not adequately taken into consideration by the Sentencing Commission." ${ }^{104}$ Additionally, the judge determines the particular sentence to be imposed under the Guidelines by considering a plethora of factors vague enough to give the judge broad discretion. ${ }^{105}$ Through these provisions of the Sentencing Guidelines, courts do have the flexibility to enhance the penalties of the defendants who pose a greater risk to schoolchildren, and who are thus more deserving of punishment, while eliminating or reducing the punishments of those who do not.

This solution was discussed briefly by the Third Circuit in Rodriguez: "If a trial court is actually presented with one of these extreme cases, we believe the Sentencing Guidelines would generally permit the court to eliminate any unwarranted increase in the sentence that would otherwise be imposed."106 The Rodriguez court explained that usually convictions under the schoolyard statute involve a one- or two-point increase in the offense level under the Sentencing Guidelines. Therefore, the court concluded, if a defendant technically qualifies for the enhancement "but it is clear that the defendant's conduct did not create any increased risk for those whom the schoolyard statute was intended to protect, we believe that a one- or two-point downward departure to eliminate this increase would be permissible."107

The D.C. Circuit in McDonald also supported this approach, stating that "[i]f lenity is appropriate in a particular case, a downward departure pursuant to the Sentencing Guidelines is the means for exercising it." Bes Because the Guidelines "do not

${ }^{104} 18$ USC $\S 3553(\mathrm{~b})$ (1994).

${ }^{205}$ See 18 USC § 3553(a) (1994):

The court, in determining the particular sentence to be imposed, shall consider-

(1) the nature and circumstances of the offense and the history and characteristics of the defendant;

(2) the need for the sentence imposed-

(A) to reflect the seriousness of the offense, to promote respect for the law, and to provide just punishment for the offense;

(B) to afford adequate deterrence to criminal conduct;

(6) the need to avoid unwarranted sentence disparities among defendants with similar records who have been found guilty of similar conduct.

For support that there remains ample opportunity for the exercise of judicial discretion under the Sentencing Guidelines, see Gerald B. Tjoflat, The Untapped Potential for Judicial Discretion under the Federal Sentencing Guidelines, 55 Fed Probation 4 (Dec 1991) (admonishing critics for "fail[ing] to appreciate the significant discretion the sentencing judge retains under the guidelines").

${ }^{106} 961$ F2d at $1095 \mathrm{n} 8$.

${ }^{100}$ Id.

${ }^{106} \mathrm{McD}$ onald, 991 F2d at 871. 
specifically address situations in which the fit is poor between the offense and the purpose of the statute violated," the court concluded that it might be a factor not adequately considered by the Commission and thus open to judicial discretion. ${ }^{109}$ However, the district court in Alston refused to follow the McDonald court's advice when faced with a transient offender. Rather than adjusting Alston's sentence down through the sentencing guidelines, the court dismissed the charge entirely and stated that the McDonald court "simply did not visualize [this] situation." ${ }^{110}$ Exactly why the Alston court chose this method to achieve the desired result, rather than through the Federal Sentencing Guidelines as proposed by the D.C. Circuit, is not clear.

Relying on the Sentencing Guidelines gives judges control to sort defendants on a case-by-case basis. If this discretion is exercised properly, the more blameworthy offenders (the permanent resident defendants) will receive the full enhanced penalties, while the less culpable offenders (the transient defendants) will receive lesser sentences through the judge's discretion. Unlike the other option of relying on Congress to amend the statute, courts need not be concerned about overcoming legislative inertia and the possibility that congressional apathy will allow the culpable defendants to escape the statute under this approach.

Furthermore, as a deterrent against the targeted criminal conduct, this proposal comports with the concept of "acoustic separation." This theory posits that, when a court sets out one standard as the rule of law (the "conduct rules"), while following another in practice (the "decision rules"), a desired deterrent effect can often be achieved. ${ }^{111}$ In the case of the schoolyard statute, the rule of law would remain the broad interpretation of "intent" to mean "intent to distribute anywhere." A defendant who possesses controlled substances within one thousand feet of a school with the intention of distributing them outside of the school zone is violating the letter of the law. However, following the "acoustic separation" approach, defendants who do not significantly increase the danger of schoolchildren are afforded lenity under the judge's sentencing discretion. Acoustic separation would explain the effect of this practice on potential offenders. Those who know about the law and its common exceptions will not be able to rely confidently on the court to grant them a reprieve from the statute should they be convicted. Therefore, it will be in their best in-

\footnotetext{
${ }^{109}$ Id at 870.

${ }^{110}$ Alston, $832 \mathrm{~F}$ Supp at 7.

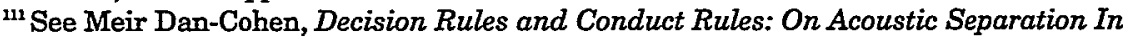
Criminal Law, 97 Harv L Rev 625, 650-51 (1984).
} 
terest to learn where school zones are and move their drug activities outside of these zones. These individuals are more likely to be the dealers who have prolonged, significant, on-going, and extensive drug activities within a school zone. In other words, the permanent resident offenders are more likely to know both where the school zones begin and end and, due to their extensive drug activities, what the relevant laws dictate. These defendants are then not likely to be less deterred from moving their activities away from schools simply because courts are known to make occasional exceptions to the statute.

The transient defendants, on the other hand, have a much more remote connection to school zones and to the laws applying to these areas. Because their activities involve shorter time periods and less significant dangers to children, these offenders are less likely to know the boundaries of the school zones and the applicable laws. Therefore, these defendants are not likely to step up their prohibited activities within school zones simply because of the potential for leniency.

Although there are many positive aspects of this proposal, there are just as many negative considerations. First is the great potential for a lack of uniformity among courts. As with any situation where justice relies on individual discretion, one cannot be confident that judges will exempt all transient offenders from the enhanced penalty while consistently increasing the punishments of the more culpable permanent resident offenders. Similarly, more of the power to distinguish between these defendants may be shifted to prosecutors. ${ }^{12}$ Without a congressional amendment, the courts will not have a uniform set of factors to consider when deciding whether or not to impose the penalties of the statute. Although such an amendment would not remove all judicial discretion, a list of relevant factors to consider would add greater uniformity to the sentences imposed by judges throughout the country.

The potential for a lack of uniformity may also raise equal protection issues. If the point of this proposal is to increase the punishment of offenders who endanger the safety of schoolchildren more than the punishment of offenders who impose a less significant risk on children, then a non-uniform application of the statute may be either underinclusive or overinclusive. It could be underinclusive if some judges decrease the penalties of some permanent resident offenders who pose a significant risk to chil-

\footnotetext{
${ }^{112}$ See Deiss, Comment, 1994 U Chi Legal F at 419 n 4 (cited in note 97) ("Prosecutors have extraordinary discretion at virtually every stage of the prosecution.").
} 
dren while other judges do not. Similarly, it could be overinclusive if some courts grant leniency for transient offenders while others do not. ${ }^{113}$ Either way, it would not be treating similarly situated defendants alike.

Additionally, the lack of guidance from the legislative branch opens the door for judicial lawmaking. In essence, courts following this approach will be recognizing exceptions to a statute that Congress did not enact and the President did not sign, thus violating the constitutional mandate under Article I of bicameral consideration and presentment. ${ }^{114}$ Congress is democratically elected and is therefore more accountable to the electorate. Also, Congress is the body of government equipped to deliberate and debate an issue. For a topic as controversial as illegal drugs and schools, it is important to preserve the deliberation and debating steps of the legislative process. Although there are strong arguments that this proposal mirrors Congress's intentions in enacting the schoolyard statute, a clearer signal from the lawmaking branch would eliminate the potential for judicial overreaching.

Proper notice is another concern. An approach such as this one, which in essence dictates an exception to a statute without codifying it, does not give citizens the proper notice that their activities may or may not be subject to punishment under the schoolyard statute. A response to this argument is that the schoolyard statute does not criminalize previously non-criminal behavior, but rather enhances penalties for already illegal activities. Therefore, the affected defendants have already been put on notice that their conduct is prohibited. Additionally, under an acoustic separation theory there is notice of criminal liability. Only those offenders eligible for judicial lenience lack notice of that eligibility.

B. A Proposal to Interpret the Statute Narrowly and Defer to Congress for Amendment

The courts' other option to address the ambiguities in the schoolyard statute is simply to interpret the statute narrowly to exclude cases that lack evidence of intent to distribute outside

\footnotetext{
${ }^{113}$ Cases challenging other parts of the schoolyard statute on equal protection grounds for being "overinclusive" or "underinclusive" have failed. Those cases, however, all involved the penalty enhancements for the sale of narcotics within the zone versus sales outside of the zone. See, for example, United States $v$ Campbell, 935 F2d 39, 45 (4th Cir 1991) (finding that Congress's actions were "rationally related to a legitimate government interest"); United States $v$ Crew, 916 F2d 980, 983 (5th Cir 1990) (same); United States $v$ Cross, 900 F2d 66, 68 (6th Cir 1990) (same).

${ }^{11}$ US Const, Art I, \$ 7, cl 2.
} 
the zone. This solution allows Congress to amend the statute to achieve greater specificity if it dislikes the courts' narrow interpretation.

In Rodriguez, the Third Circuit recognized the difficulties of applying the schoolyard statute to these borderline defendants: "No matter how interpreted, the coverage of the schoolyard provision would not correspond precisely with the class of cases involving increased risk to students."115 The court understood that the narrow interpretation "would make the statute inapplicable in several situations in which the mere possession of sizable quantities of drugs near a school would create an increased risk for students." However, the Rodriguez court concluded that this amount of "imprecision" in the statute was inevitable. ${ }^{117}$ Congress was faced with a difficult decision, the court explained, between choosing either (a) requiring proof of intent to distribute within the school zone and thus not covering situations "in which the mere possession of sizable quantities of controlled substances near a school would pose an increased risk to students," or (b) not requiring such proof and making the statute applicable in situations "involving no increased risk to students."118

The Rodriguez court's analysis of Congress's options as essentially all-or-nothing was incomplete. Congress had, and still has through the amendment process, the option of developing a list of relevant factors relating to whether an activity significantly increases the risk to students and therefore should be punished under the schoolyard statute. For example, Congress can state that, in order to enhance the sentence of a defendant who is charged with possessing controlled substances within a school zone, with the intent to distribute them outside of the school zone, the prosecution must prove that the defendant "significantly increased" the risk to schoolchildren of dangers associated with controlled substances, including exposure to illegal drugs and drug-related violence.

If Congress reaches conclusions similar to those of this Comment, the amended statute could require consideration of the duration of the possession within the school zone, the quantity of the controlled substances involved, and whether the offender had an established foothold or residence within the school zone. With additional guidance, the courts could properly decide these questions, allowing the community to determine which de-

\footnotetext{
${ }^{125} 961$ F2d at 1094.

${ }^{116} \mathrm{Id}$.

${ }^{117}$ Id at 1095.

${ }^{118}$ Id.
} 
fendants endangered the children more and which endangered them less.

It is also possible that Congress could present these factors as guidance to be used by courts in sentencing. Once a defendant is convicted under the schoolyard statute, judges could turn to this list of congressionally enacted factors when determining whether or not the offender deserves the full force of the statute or a lesser sentence. The result would be similar to that of the proposal suggested above that relies on the Federal Sentencing Guidelines. Here, however, the courts would have the benefit of congressional guidance when making sentencing decisions, thus creating greater uniformity and avoiding the problem of judicial activism.

This approach, like the first discussed above, would separate the permanent resident offenders from the transient offenders. If Congress intended to increase the punishment for drug dealers whose conduct significantly increases the danger to schoolchildren, underenforcement of the statute by the courts should cause legislators to take action and state more clearly which offenders should receive the enhanced penalties.

A list of factors for courts to consider in cases where defendants possessed within the school zone with an intent to distribute elsewhere would separate the more culpable from the less culpable and ensure greater uniformity within the judicial system. Alternatively, if Congress did not intend to distinguish between the two groups of defendants, a grammatically unambiguous statute clarifying the mens rea requirement would give courts the direction they need to carry out Congress's intentions. Finally, if Congress did intend a narrow interpretation of the statute such that the courts are in fact interpreting it correctly, it can simply acquiesce, leaving the statute untouched. It is certainly possible that the implicit distinction being made by the courts is simply wrong. If so, it is constitutionally more proper for courts to demand specificity and then to adjudicate laws that they know Congress intended.

The strongest argument against this proposal to send the statute back to Congress is that of legislative inertia. Relying on Congress to amend the statute leaves the courts with the risk that Congress will fail to act and therefore allow blameworthy defendants to avoid the added punishment that Congress intended them to receive. The weight of the legislative workload, the difficult and time-consuming process of amending a statute, and the number of issues demanding immediate attention all minimize the chance that Congress will address the issue again. 
Therefore, courts risk imposing an erroneous interpretation of a statute for years and possibly decades. ${ }^{119}$ However, if any issue in criminal law today will catch the legislators' attention, it is one involving both illegal drugs and schoolchildren. Congress has already amended this statute twice. Furthermore, the issue of drug use among teenagers was a major issue during the 1996 election campaigns of presidential candidates Bill Clinton and Bob Dole that resulted in a slew of television attack ads from both major parties. ${ }^{120}$ The pervasive controversy surrounding illegal drugs and their effects on children renders considerably smaller the fear that Congress will turn its back on this issue.

\section{CONCLUSION}

A fact-based analysis of the relevant cases under the schoolyard statute reveals that courts generally agree on the types of drug dealers who should receive the heightened penalties of the statute and those who should not. The more culpable offenders are those who have an established foothold in the school zone through prolonged, substantial, and ongoing drug activities. These permanent resident offenders significantly increase the danger that schoolchildren will be affected by illegal drugs or drug-related violence. The less blameworthy offenders are those who have a fleeting, temporary, and less extensive association with the school zone. These transient offenders are less likely to lure students into drug use or expose them to drug-related violence.

Courts could consider interpreting the statute broadly to include all of these defendants and afford lenity to the transient offenders through their discretion under the Sentencing Guidelines. However, because of the constitutional concerns about judicial lawmaking, lack of uniformity, entrapment, and equal protection, there is a better option. Federal courts could interpret the "possessing with intent to distribute" portion of the schoolyard statute narrowly to exclude cases that lack evidence of intent to distribute within the zone. If the judiciary is indeed underenforcing the statute through its narrow interpretation, Congress bears the burden of amending the statute if a distinction between permanent resident and transient offenders was intended. If Congress did not intend such a distinction, it can clar-

${ }^{119}$ See S. Fred Singer, Overdue Farewell to the Delaney Clause?, Wash Times A21 (July 12, 1995) (applauding the repeal of a 1958 law which banned any food additive shown to cause cancer in lab animals).

${ }^{120}$ See Paul Miller, Teenage Drug Abuse is a Prominent Campaign Issue, NPR, Morning Ed (Sept 19, 1996). 
ify which defendants should be punished more severely. Finally, if the courts' narrow interpretation comports with congressional intent, Congress can simply acquiesce. 